
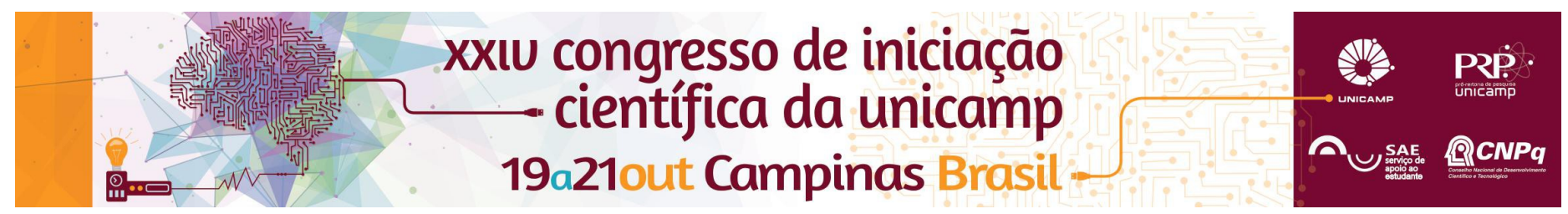

\title{
O Livro de Cabeceira: A Imagem-Texto que se dá no corpo
}

\section{Adriano R. C. de Lima}

\section{Resumo}

Análise fílmica do longa-metragem "O Livro de Cabeceira" (The Pillow Book, 1996), de Peter Greenaway, buscando refletir os elementos estéticos e narrativos do filme que trabalham a associação e a mistura entre a imagem e o texto escrito, como essa mistura se relaciona com o discurso do filme centrado no corpo (e no erotismo), e de que forma este filme e o restante da obra do diretor buscam uma contestação sobre a condição do cinema dentro de nossa cultura visual contemporânea.

\section{Palavras-chave:}

O livro de cabeceira, Peter Greenaway, corpo no cinema;

\section{Introdução}

A narrativa de "O Livro de Cabeceira" foca-se na personagem Nagiko, uma mulher natural do Japão cujo fetiche é que seus amantes escrevam pelo seu corpo. No decorrer do filme, que utiliza múltiplas imagens e textos se sobrepondo e se sobreenquadrando, compondo um mosaico heterogêneo mais aproximado da estética da New Media. Essa pesquisa busca refletir como Greenaway trabalha a noção de uma apreciação visual e não apenas denotativa do texto, configurando a mistura que chamo de "Imagem-Texto". A predominância da escrita oriental no filme reforça a proposta do diretor, pelo fato dos ideogramas japoneses e suas correlações funcionarem em essência como imagem e texto ao mesmo tempo.

O corpo da personagem e suas relações são centrais no filme, que trata uma mulher buscando sua liberdade sexual e independência. Ao ter seu corpo preenchido de ideogramas (e em dado momento de escrita ocidental) pelos seus amantes, uma relação entre a escrita e a corporalidade se evidencia cada vez mais no filme. Ela escreve em seu livro de cabeceira, diário íntimo de vivências e reflexões, sobre seus casos amorosos, e é possível ver que assim como o ato de escrever está associado ao sexo. Essa pesquisa também busca aprofundar essa relação do texto (que também se apresenta e se afirma em caráter imagético) com a corporalidade.

\section{Resultados e Discussão}

Através de um estudo amplo da filmografia, dos textos e dos relatos do diretor, pôde-se confirmar seu intuito em subverter as relações tradicionais entre cinema $e$ literatura, pois ele acredita que o cinema deve buscar ser menos literário e narrativo, e mais embasado na natureza flutuante da imagem. Em diversas obras ele busca a Imagem-Texto para reforçar esse caráter, e utiliza dos novos avanços tecnológicos de concepção imagética para sofisticar cada vez mais sua empreitada.
Além disso, as múltiplas associações do sexo com a escrita, do corpo com o livro, a atração sexual com a caligrafia, e a conclusão de um texto como o nascimento de uma nova vida, desenrolam-se na narrativa afirmando que assim como Nagiko descreve sua vida em seu livro de cabeceira, ela vive em sua materialidade corporal. O corpo, grande objeto de reflexão na pós-modernidade, é tido como afirmação da existência, cerimoniado nesse ato de criação da escrita (e da imagem).

Além disso, no mesmo contexto de avanços tecnológicos e suas consequências na cultura contemporânea, a passagem do texto à mão (feito pelo corpo) para a datilografia e a digitação é tido como um rompimento entre o corpo e a escrita, afastado pela protagonista que anseia pela união dos dois. E, da mesma forma, a datilografia e a digitação também rompem com o forte potencial imagético do texto (sua caligrafia) trabalhado no filme.

\section{Conclusão}

O filme "O Livro de Cabeceira" trata-se de uma obra complexa, e pode ser compreendido de várias formas e em múltiplas abordagens. $O$ estudo de suas particularidades no tratamento do texto e do corpo em sua narrativa e em sua mise-em-scène (combinados ou separados), permitem compreender toda uma grande perspectiva à cerca da cultura contemporânea, seja em aspecto visual, textual, corporal, performático. Greenaway busca um cinema mais livre, da mesma forma que Nagiko busca a liberdade para seu corpo e sua vontade de escrever.

\section{Agradecimentos}

Agradeço desde já meu orientador Francisco Elinaldo Teixeira, por todo o apoio, pelas discussões, e pelo auxílio nessa pesquisa tão complexa. Agradeço à Unicamp, e ao PIBIC pela oportunidade e pelo aprendizado. Agradeço também a meus companheiros, de norte a sul, que me acompanham e fazem desse mundo de questões e problematizações um lugar mais tranquilo. 